\title{
Cikkismertetés: E-egészség és a csecsemőkori egészséges táplálkozás
}

\author{
Article review: An eHealth intervention and healthy eating in infancy
}

$\begin{array}{ll}\text { Ismertető: } & \text { Fromvald Tamás } ₫ \\ & \text { Nemzeti Népegészségügyi Központ }\end{array}$

Ismertetett cikk: Helle C, Hillesund ER, Wills AK et al. Evaluation of an eHealth intervention aiming to promote healthy food habits from infancy - the Norwegian randomized controlled trial Early Food for Future Health. Int J Behav Nutr Phys Act. 2019 Jan 3;16(1):1.

doi: 10.1186/s12966-018-0763-4

Beküldve: $\quad$ 2019. 01. 28.

doi: $\quad$ 10.24365/ef.v60i2.412

Kulcsszavak: egészséges táplálkozási szokások; csecsemőkor; elhízás

Keywords: healthy food habits; infancy; obesity

\section{HÁTTÉR}

A gyermekkori túlsúly és az elhízás világméretű elterjedtsége hatalmas népegészségügyi probléma. Emiatt hatékony és könnyen megvalósítható eszközökre van szükség, amelyekkel csökkenthető a gyermekkori elhízás és túlsúly mértéke. A kora gyermekkor szenzitív periódus a táplálkozási szokások kialakításához, ezért a korai táplálkozás optimalizálására irányuló stratégiák fontos lehetőséget jelenthetnek a túlsúly és az elhízás megelőzésére. A szülők szerepe a csecsemők táplálkozási preferenciáinak és étkezési szokásainak kialakításában alapvető fontosságú, és ugyancsak ők a kora gyermekkorban kezdődő primer prevenció kulcsfontosságú szereplői. Egy 2016-ban megjelent szisztematikus összefoglalói szerint a csecsemőés kora gyermekkori túlsúly, valamint elhízás kockázatának csökkentésére azok a legígéretesebb elhízás-megelőzési stratégiák, amelyek az étrendre és az étkezési szokásokra összpontosítanak.
Az általunk bemutatott tanulmány erre az eredményre alapozva vizsgálta a kora gyermekkorban történő e-egészség intervenció hatásosságát.

Az online elérhető információk potenciálisan növelhetik a szülői ismereteket és készségeket, ugyanakkor könnyen érthetőek és hozzáférhetők. A webalapú viselkedésváltozási beavatkozások hatékonyságára vonatkozó kutatások ígéretesek, azonban közülük csak nagyon kevés értékelte a csecsemőtáplálására vonatkozó beavatkozások hatékonyságát.

A kutatás az e-egészség beavatkozás eredményességét értékelte a szülők gyermektáplálási szokásain keresztül.

\section{MÓDSZER}

A szülőket a közösségi média és gyermekklinikák közremúködésével toborozták 2016 tavaszán, amikor gyermekük 3-5 hónapos volt. Összesen 718

\footnotetext{
i Redsell SA, Edmonds B, Swift JA et al. Systematic review of randomised controlled trials of interventions that aim to reduce the risk, either directly or indirectly, of overweight and obesity in infancy and early childhood. Matern Child Nutr. 2016;12:24-38. doi: 10.1111/mcn.12184
} 
szülő töltötte ki az online kérdőívet gyermekük 5,5 hónapos korában. A résztvevőket két csoportba osztották. Az egyik csoport tagjai az e-egészség platformon keresztül havi rendszerességgel tekinthettek meg rövid videókat, amin gyermekük életkorának megfelelő csecsemő-étkeztetési témákat és bébiételrecepteket tettek közzé 6-12 hónapos korig. Ezalatt a kontrollcsoport tagjai általános gyermek-egészségügyi ellátásban részesültek, vagyis a gyermekek fejlődését 6, 8, 10 és 12 hónapos korukban vizsgálták. A konzultációkon a magyar védőnőkhöz hasonló funkciót betöltő közösségi ápolók ellenőrizték a gyermekek súlyát és hosszát, valamint a gyermekek egészségével, növekedésével és pszichomotoros fejlődésével kapcsolatos beszélgetésekre is sor került. A vizsgálatban résztvevő gyermekeket 6 és 12 hónapos korukban gyermekorvos is megvizsgálta.

A kutatás során az elsődlegesen vizsgált tényezők a gyermekek táplálása, tápanyag bevitele és étkezési szokásai, valamint a szülők gyermektáplálási stílusa voltak. Másodlagos tényezőként pedig a gyermekek születésekor mért, valamint a 12 hónapos korban történő antropometriai vizsgálat eredményei szerepeltek a kutatásban.

\section{EREDMÉNYEK}

\section{Étkezési szokások}

Azon csoport tagjai, akik hozzáférést nyertek az e-egészség platformhoz, gyakrabban kínáltak gyermeküknek gyümölcsöt és zöldséget $(p=0,035)$, valamint a zöldségek szélesebb skáláját kóstoltatták meg $(p=0,015)$ a kontrollcsoporthoz képest. Ugyancsak az első csoportba tartozó szülők közül számoltak be arról többen, hogy a család együtt reggelizett és vacsorázott ( $p=0,035)$, valamint ritkábban néztek tévét az étkezések alatt $(p=0,009)$. Az e-egészség platformhoz hozzáférő szülők több, mint 80\%-a tekintette meg a táplálkozási tanácsokkal foglalkozó teljes videóanyagot, amit jól felhasználhatónak, gyermekük korához illeszkedőnek talált.

\section{Antropometriai adatok}

Nem találtak antropometriai különbségeket a két csoport között.

\section{Korlátok}

A tanulmány kivitelezésében nehézséget jelentett, hogy a jelentkezők viszonylag magas számához képest a vártnál alacsonyabb volt azok aránya, akik a vizsgálat végéig részt vettek a kutatásban. Továbbá sok jelentkező lemaradt az első vizsgálatról. Valószínú, hogy egy nagyobb elemszámú csoporttal végzett kutatás lehetővé tenné az eredményének szélesebb körben történő elismerését.

\section{KÖVETKEZTETÉSEK}

Az eredmények arra utalnak, hogy az e-egészség platform megfelelő eszközként használható arra, hogy a csecsemők egészséges táplálására vonatkozó információkat átadják a norvég szülők számára. A vizsgálat azt is sugallja, hogy az így történő információátadás a korai gyermekétkeztetésre vonatkozóan növelheti a fiatal gyermekek napi zöldség- és gyümölcsbevitelét, valamint elősegítheti a kedvező étkezési szokások kialakítását. A hosszabb távú hatások megismeréséhez és értékeléséhez további utánkövetéses vizsgálatok végzése szükséges a jövőben.

\section{TANULSÁGOK A HAZAI SZAKEMBEREK SZÁMÁRA}

A kutatás eredményeiből kiindulva láthatjuk, hogy a szülőknek jelentős szerepe van a csecsemők egészséges táplálásában, valamint a későbbi étkezési szokások kialakításában. Mivel az internethasználat és a közösségi média egyre nagyobb teret nyer mindennapi tevékenységeink során, így a prevenció területén is használható eszközként tekinthetünk rá. Javasolnám egy, a norvég mintára történő itthoni kutatás lebonyolítását nagyobb elemszám bevonásával. 